\title{
SATIRE LANGUAGE STYLE BY BU TEJO IN THE SHORT FILM “TILIK”
}

\author{
Nawang Asri Ayuningtyas, Sulis Triyono
}

\author{
nawangasri04@gmail.com \\ Universitas Negeri Yogyakarta \\ Yogyakarta, Daerah Istimewa Yogyakarta, Indonesia
}

\begin{abstract}
The use of satire language style by a film creator aims to convey meaning to the public. This study aims at analyzing the use of satire language styles used by Bu Tejo in a short film entitled "Tilik." This research used a qualitative descriptive method. The object of this research is satire utterances spoken by Bu Tejo in the film "Tilik." The data collection techniques in this study used observation, listening, and note-taking techniques. The results demonstrate three types of satire languages used by $\mathrm{Bu}$ Tejo in the film "Tilik": cynicism, irony, and sarcasm. It is also found that cynicism is the most spoken language than sarcasm. The study highlights that the use of satire language uttered by $\mathrm{Bu}$ Tejo aims to convey ideas and perspectives related to problems occurring in society and express dissatisfaction.
\end{abstract}

Keywords: language style, satire, the short film "Tilik."

\section{BACKGROUND}

Literary works are delivered in poetry or novels and conveyed through films in this modern age. The film is a literary work that can be explained as a textual framework, with various ways of presenting the film depending on the characteristics contained in the literary text. The film is a contemporary movement that shifts from a literary mode to a visual literary mode (Klarer, 2004). According to Walter Benjamin, the film is not only a reflection of existing reality but can also be viewed as a process of creating reality itself. As a result, the film becomes a work of art in the form of a medium for delivering a message derived from phenomena, whether they are real-life events or the filmmaker's imagination (Siregar, 2011; Permana et al., 2019). Depending on the director's mission, the message the filmmaker wishes to convey to the audience may take the form of sound, conversation, action, or others. The film is made to tell a story about a life taken from someone's life as a storyline written so that the storyline can influence the listeners or readers (Nurlia et al., 2019). Thus, a film is a literary work that tells a story that occurs in people's daily life or the imagination of a filmmaker who wishes to communicate a specific message to the entire community in its realization.

The use of language style by the author is not only to convey his thoughts but also to deliver other information that the author or speaker does not explicitly state. As a result, several factors cause both writers and speakers to prefer to communicate the information using language styles (Subandi, 2015, as cited in Subandi \& Galih Wibisono, 2017). First, the style of language used by the movie's creators in the story or the character played by someone is a particular color for the audience. The style of language used by the film's creators in the story or the character played by someone is a color to the audience. The style is selected because of its uniqueness, enabling readers or listeners to distinguish each author's work. Also, the style of language uniquely expressed by each author has the intention to convey the objectives to the greatest extent possible (Masni \& Yani, 2019). Although the two authors share the same idea, the style of language that each of the authors will convey is different and has its distinctive characteristics (Halimah \& Hilaliyah, 2019). 
The satirical style is frequently used in everyday life by community members and authors of literary works to disseminate information that is not approved. Satire is a language used for a specific purpose and contains the inverse meaning of what someone says. Satirical words are spoken or conveyed in the hidden, inaccurate, and figurative language associated with other matters but have a purpose addressed correctly to someone (Keraf, 2007). Satire language is also known as the language with variety because it is used by someone aware of the appropriate situation and context. The satire language is spoken in one or two words, but the expression implies the meaning (Rashid \& Yaakob, 2017). Someone's use of satirical language is one method of carrying out the expressive function of language in communication. The emotive function of language in question is the ability to express one's feelings against a backdrop of displeasure, annoyance, hatred, and other negative feelings expressed through words in the form of satire (Arisnawati, 2020).

In discussing satire language, fulfilling the expressive function of language, Jakobson (cited in Wijana \& Rohmadi, 2006) states that the expressive function, along with five other language functions such as conative, referential, metalingual, poetic, and phatic, is one of the essential functions in language. Meanwhile, Leech (in Wijana \& Rohmadi, 2006) identifies five different formulations of Jakobson's language functions: informational, expressive, directive, aesthetic, and phatic. Satire language is one of the manifestations of expressive functions. The expressive form of satire language includes expressions of protest shown by someone for things that are deemed inappropriate, delivered in a subtle but unpleasant tone of voice. Someone who uses satirical language does so with the intent of being sarcastic and indirectly mocking.

Satirical language is also used in everyday life, and some filmmakers choose to use satirical language in their films to convey the intended messages. For example, the researcher chose a satire language style in the short film 'Tilik' made in 2018 by the production house Ravacana Films. In 2020, the film 'Tilik' became viral among the Indonesian people and was considered entertainment during the pandemic Covid-19. The film "Tilik's" popularity can be seen in the memes of film quotes used in chat for stickers, footage from the film, and other digital forms frequently seen on social media. Bu Tejo's character, in particular, went viral because the public perceived her as a character who fits the stereotype of womankind who likes to gossip and comment on other people's affairs in a sarcastic tone. Additionally, the film 'Tilik' shows a reality of life in the Indonesian community, representing the habits of Indonesian social neighborhood characteristics.

The film Tilik was directed by Wahyu Agung Prasetyo. In Javanese, tilik means to visit sick people. As the title suggests, this film tells the story of mothers living in a village who traveled by truck to visit their headman in the hospital. Along the way, BuTejo, played by Siti Fauziah, was the one who replied to the conversation opened by Yu Sam. She continued the conversation about Dian, the most beautiful woman in their village who still had a single status while Dian's friends were married. In addition, Bu Tejo also mentioned that Dian had just started working, but she could already buy expensive things. Therefore, bu Tejo suspected that Dian was a "naughty" woman and spread the rumors to other female villagers joining the trip. Bu Tejo's response and a sarcastic tone in replying to Yu Ning's (Brillianan Desy) neutral comments to the rumors made the atmosphere even more heated when discussing Dian during the trip to the hospital. Therefore, Bu Tejo's sarcastic utterances are interesting to be analyzed to reveal how she uttered the sarcastic language.

Research related to language style is not new. The previous research related to language style was carried out by Masni \& Yani (2019), titled "Forms of Satire Language Style in Comic 8 Kasino King Part 2 Film by Anggy Umbara (Structural Analysis)". The research examined the satirical language style using structural analysis with theoretical concepts belonging to Tarigan, Keraf, and Purwandi to examine the style of satire in the Comic 8 Kasino King Part 2. The results of this study are the use of satire language style in the Comic 8 Kasino film, It is found that (1) there are 17 forms of ironic satire language style in conversation quotes including "smell of hair" and "eh longish." (2) there are five forms of satirical cynicism which were found in several conversation quotes, including cowardice, sissy, and murderous 
power. (3) there are eight forms of sarcasm satire, the crudest form of satire found in conversation quotes: being crazy, being stupid, and using tiny brains. The satire language style research conducted by Halimah \& Hilaliyah (2019) examined Najwa's Notes' satire language style using content analysis techniques. The results of the study showed that the book 'Najwa's Notes' uses satire language styles including (1) Irony as much as $20 \%$; (2) Cynicism as much as $40 \%$; (3) Innuendo as much as 10\%; (4) Sarcasm as much as 16\%; and (5) 10\% satire. Najwa Shihab does not use satire, meiosis, and antiphrases in the book 'Najwa's Notes.' The cynicism style was the language style Najwa Shihab chose in her book to convey her opinion regarding an issue in society. Arisnawati also conducted a similar study (2020), entitled 'Style of Satire as a Form of Indirect Communication in Laiyolo Language' in her research concluded that the style of satire used in Laiyolo language as an indirect form uses three types of satire language, namely irony, cynicism, and sarcasm. These three language styles contradict the principles of cooperation and politeness held by the Lailoyo community. However, the forms of the three satire language styles are considered by Lailoyo language users to be safer to say than criticizing, insulting, and mocking.

The similarity of this research with previous research is to analyze the use of satire language style in a literary work, based on the previous studies mentioned above. The focus of satire language style of the main character, Mrs. Tejo, who was described as the reality of neighboring married females who at times liked to comment on other people's affairs with satire language to add to the impression in the conversation, distinguishes this study from previous research. Thus, the director presented in the short film the reality of chats and the women's behavior in that society.

\section{METHOD}

The method applied in this study is descriptive qualitative research. The purpose of this study was to gain an overview of the employment of satirical language styles such as irony, cynicism, and sarcasm in Wahyu Agung Prasetyo's 2018 film "Tilik." The speech spoken by Bu Tejo-Bu Tejo means Mrs. Tejo- in the short film "Tilik" on YouTube serves as the basis for this investigation. Therefore, this study aimed to examine the satirical language style employed by Bu Tejo in the short film.

The subject of this study is derived from the data collected (Arikunto, 2010). The data for this study comes from the film 'Tilik,' which focuses on the character of $B u$ Tejo with her use of satirical language. The character of $B u$ Tejo was chosen as the data source because, throughout the conversation on the trip to the hospital as told in the film, Bu Tejo used satire when speaking about Dian or responding to conversations with the other women.

The data was collected through observation, listening, and note-taking. The researchers started by transcribing the utterances in the short film 'Tilik.' The second phase examines the transcript and video concentrated on the issue that the researcher would investigate in terms of Bu Tejo's satirical language style. The third phase is to document and categorize the satire employed by $\mathrm{Bu}$ Tejo in the short film 'Tilik.' The fourth stage is $\mathrm{f}$ assessing Bu Tejo's speech, which contains the language style observed in the transcript. The researcher used data cards in this study. The data analysis methodology used in this study is a practical matching method integrated with the Determinant Element Technique (PUP).

\section{RESULT AND DISCUSSION}

According to the KBBI (the Great Indonesian Dictionary), the term 'satir' (Indonesian term for satire) is derived from the root word 'sindir,' which implies "a statement designed to insinuate others, reproach, or ridicule covertly." In other terms, satire is a subtle type of censure or ridicule directed at someone when they express a protest (Mara \& Bahry, 2019). In addition, a satirical language style is one in which sentences are spoken to insinuate someone or the conduct and conditions that occur (Tarigan, 2013).

$B u$ Tejo's use of satire in the film 'Tilik' occurred frequently. It is motivated by $B u$ Tejo's attitude, in which she believed she knew everything about Dian, which was not always accurate and stemmed from social media or other people's conversations. Bu Tejo thought that Dian's actions were questionable. Bu. Tejo also employed satirical language to reinforce that what she was saying was true. Someone who satirizes others appears to want to 
demonstrate that they have better actions and views than the targets of satire.

Based on the result of the study, the researcher found that $\mathrm{Bu}$ Tejo used three types of satire language styles during the conversation happening in the film. Table 1 summarizes the data on Mrs. Tejo's use of satirical language style:

Table 1. The Use of Bu Tejo's Satirical Language Style in the Short Film "Tilik"

\begin{tabular}{ll}
\cline { 2 - 2 } Satirical Language Style & Total \\
\hline Cynicism & 8 \\
Irony & 3 \\
Sarcasm & 2
\end{tabular}

The data analysis results presented in the table above shows that $B u$ Tejo used 13 different types of satire in the film 'Tilik,' including irony, cynicism, and sarcasm. Cynicism became the most prevalent satirical language style employed by $B u$ Tejo in conversation, whereas sarcasm became a satirical language type that was used sparingly.

Cynicism is a satirical language style that is more abrasive than irony. Bu Tejo primarily used cynicism in the film 'Tilik' to convey feelings or opinions about something she disagreed with by mocking and looking down on her interlocutor's viewpoints. Each conversation $\mathrm{Bu}$ Tejo had contained a cynical satire expressed in an evident tone of displeasure, despite the interlocutor's attempts to provide rationales for Dian's action or to persuade Bu Tejo to consider Dian's life positively. On the other hand, $\mathrm{Bu}$ Tejo responded sarcastically, joking but appearing cynical to demonstrate that she had reservations about a statement by looking down on Yu Ning's defense of Dian. Solekhati (2016) asserts that employing a cynical language style has a rougher measure than using ironic satire to insinuate someone with the form of ridicule that looks down on and casts doubt on a person's statements and doubts. Additionally, the appropriate words can create the impression of satire to convey feelings of annoyance. Thus, while cynical satire uses subtle language, it can turn harsh when the expressions employed are replaced with ones intended to demean and ridicule someone.

$B u$ Tejo's speech in the film 'Tilik' employs a humorous language style with delicate wording, yet its content directly opposes the words stated. Bu Tejo's irony style may be found in people's daily lives, particularly women gossiping about someone when a slight laugh usually accompanies said satire, yet the tone and language used are intended to be sarcastic without intending to hurt people. Irony is a type of satire in which subtle mockery is used, but the genuine meaning is contradicted (Mara \& Bahry, 2019). $\mathrm{Bu}$ Tejo's sarcastic, satirical sentences are conveyed directly to the interlocutor. Still, by employing terms opposite their genuine meanings, the interlocutor can recognize that ironic satire is revealed. This theory is consistent with Keraf's (2007) observation that an ironic, satirical language style spoken by someone to satirize will work if the speaker is likewise aware of the hidden intents underlying the string of words.

The sarcasm used in Bu Tejo's dialogue in the film 'Tilik' is only slightly similar to that of cynicism because the use of cynical satire language is considered slightly better in terms of language and meaning. The style of sarcasm may contain swearing, reproach, and ridicule, all of which can be hurtful if heard. Sarcasm is a harsher form of satire than irony or cynicism, as it incorporates scathing reproaches. Sarcasm may involve irony and cynicism, but when used, the words stated will hurt others' feelings and make the intended recipient uncomfortable (Heru, 2018). Bu Tejo's sarcasm involved reproaches that offended those who heard the satire due to the harsh language employed and the usage of unpleasing parables. Bu Tejo's use of sarcasm appears to be a direct statement of ridicule toward others, which also influences her choice of language with an unpleasant meaning to convey her feelings. It is consistent with Muhsyanur's (2015) opinion, which claims that using words with negative, unpleasant, and nasty connotations can result in poor taste and rudeness.

\section{Cynicism}

Cynicism is a language style used by someone to indicate something is wrong. Cynicism is a satirical language used to satirize doubts about a statement, someone's honesty, or sincerity (Tarigan, 2013). The following are some samples of sentences written by $\mathrm{Bu}$ Tejo 
in this study that employs the cynical satire language style;

"Bu Tejo: eh, Dian iki gawaean ne opo yo? Kok jare onok seng tau ngomong yen gawean ne ra gena ngono kuwi loh kan mesakne bu Lurah to hoho... yen nganti duwe mantu gawean ne ra gena ngono kuwi loh yo, ono seng tau ngomong yen gawena ne Dian iki mlebu metu hotel ngono kuwi loh terus neng mall karo wong lanang mbarang iki" (Hey, what's Dian's work? Someone once said that her job is not correct, such a pity for Bu Lurah. If Bu lurah has a daughter-in-law, her job is not right like that, and some say that her work is going in and out of the hotel then going to the mall with the boy).

In words, "yen nganti duwe mantu gawean ne ra gena ngono kuwi loh yo, ono seng tau ngomong yen gawena ne Dian iki mlebu metu hotel ngono kuwi loh terus neng mall karo wong lanang mbarang iki (If Bu lurah has a daughter-in-law her job is not right like that, some say that her work is going in and out of the hotel then going to the mall with the boy)," is considered a cynical style of language since it contains an inferred meaning that seeks to associate somebody with anything negative. $B u$ Tejo's words implied someone who stated that Dian's work was considered inadequate due to her frequent visits to hotels and malls with other men, although Dian's position was that of $\mathrm{Bu}$ Lurah's prospective daughter-in-law. The utterance's objective is to insinuate someone who said anything without verifying and twisting the facts. These phrases cause those who hear them create doubts about someone's credibility and negative sentiments about them. Cynicism is a language style marked by teasing, such as finding fault in others, satirical, and mocking. Thus, it affects someone's trust in commonly accepted standards and the sincerity with which they conduct themselves, as cynicism exhibits sentiments of suspicion to disrespect individuals (Keraf, 2007).

"Bu tejo: la yo Dian ki aneh-aneh wae kok wes umuran ne kok yo ora ndang rabi wong konco-konco ne wes do rabi cobo heh? (It is just Dian, who is weird, she is already old enough to get married, how is it that she is not yet married, all her friends are already married.)
"Yu Ning: na nek saiki dewek e ki pengen fokus karo karir e piye hah? Wong yo awak e dewe ki ra ngerti to sajakne kondisine de'e koyok ngopo sak tenanne (What if she wants to concentrate on a career first? We don't know what the actual situation is)

Bu Tejo: koyok urip e nduwe karir wae (As if there was a career in her life)."

The style of cynicism in conversation is found in the expression "koyok urip e nduwe career wae" (As if there was a career in her life). $B u$ Tejo used this expression in a cynical tone, mocking Yu Ning's interlocutor. Bu Tejo's comment was intended to satirize what $Y u$ Ning said by casting doubt on Yu Ning's assertion that Dian desired to focus on her career first. On the other hand, Bu Tejo appeared to have had no formal profession. $B u$ Tejo believed that marrying at the proper age was preferable to surpassing the marriage age limit and focusing exclusively on her career. $\mathrm{Bu}$ Tejo's cynical satire language style satirized her speech partner's concerns about an incident she disagreed with and responded to his partner's statement with a rather harsh choice of words. Those who heard and were targeted by the satire feel hurt. Thus, cynicism is a harsher form of irony (Ibrahim, 2015).

\section{"Yu Ning: padune ben pak Tejo seng dadi lurah iyo ra? (You mean, let Pak Tejo replaces it, right?)}

$\mathrm{Bu}$ Tejo: weee yo ora aku ki mesakne wae tenan ho'oh to... tur yo (berdeham) wes wayae desane dewe ki butuh lurah seng cak cek sak set ngono kae loh ho'oh to tur yo ora single nek single kuwi gowo urip e dewe ae abot (It's not like that, I feel sorry to the headman. Anyway, it's time for our village to have such a nimble headman, but [they are] not single, If she is single, it is difficult to look after her own life)"

The expression "tur yo ora single nek single kuwi gowo urip e dewe ae abot" (If she is single, it is difficult to look after her own life) is considered cynical of language style because, in its expression, it is mocking and despising. As can be seen, $B u$ Tejo took pity on the single $B u$ Lurah and believed that single people, particularly those who cared for others, had trouble managing their own lives. Bu Tejo wanted a leader who was not single, nimble, 
and could be relied upon to manage village affairs. Additionally, Bu Tejo believed that $B u$ Lurah should relinquish her position as lurah (chief of the village) and devote more time to $B u$ Lurah's personal affairs.

\section{Irony}

The ironic language style is a satirical one in which a speaker utilizes discreetly implied meaning and intent that differ from the words spoken (Tarigan, 2013). Although the ironic style is subtle, the satire's meaning is not the same as the genuine meaning. The following is an example of irony from $\mathrm{Bu}$ Tejo in the film 'Tilik.'

"Bu Tejo: Hehehe... mulakno Yu Ning sregep'o moco berita soko internet iyo ora? dadine iki lek dijak omong nyambung ngono loh... ho'oh to" (That's why Yu Ning diligently read the news from the internet, right? So if you talk to others, you understand)

In words, "mulakno $\mathrm{Yu}$ Ning sregep'o moco news soko internet iyo ora? dadine iki lek dijak omong nyambung ngono loh"(That's why $Y u$ Ning diligently read the news from the internet, right? So, if you talk to others, you understand), this string of words forms an ironic satire that is expressed in a subtle manner which is not too harsh and not cynical. Regarding the use of the word 'sregep,' which means 'diligent' according to the KBBI, the word diligent means doing something by continuously doing a job seriously and always trying hard. Still, the intent and purpose conveyed by the speaker have different meanings. The word 'diligent' refers to someone who does an action diligently and consistently, but the speaker's aim and intention communicate a different connotation; the word 'diligent' here refers to someone who does not perform an activity diligently and consistently. The word 'diligent' in the speech of $B u$ Tejo refers to someone who performs an activity carelessly and sluggishly. The speaker's true intention is to convey that, at the very least, Yu Ning was constantly updated on current events in her immediate environment via the internet, so that when she was asked about the news, she understood what was being said. The conversational expression demonstrates that the term chosen is the opposite of what is intended. The meaning in irony can be presented directly in a single sentence, such that what is displayed in a sentence has a contradictory meaning. The ironic language style is used by speakers to convey an implied meaning but is articulated in a neutral tone so that the genuine meaning of someone who says it must be interpreted prudently (Rashid \& Yaakob, 2017).

"Bu Tejo: Mangkane... da nduwe hp iku ra mung digawe gaya tok dienggo gawe golek informasi ngono loh" (that's why having a mobile phone is not just for pleasure, but also for finding information, you know).

In words, "nduwe hp iku ra mung digawe gaya tok dienggo gawe golek informasi ngono loh" (that's why having a mobile phone is not just for pleasure, but also for finding information, you know) the meaning of $\mathrm{Bu}$ Tejo's expression was to imply that someone had a smartphone solely to be fashionable and show off to others, rather than to obtain vital information via a smartphone, through which all information could be received conveniently and fast in our modern period. Bu Tejo's satire is not just for the interlocutor but also for the wider audience, as she conveyed the sarcasm subtly and with a different connotation. Thus, employing a sarcastic language style, whether deliberate or unintentional, can be effective if the audience understands the hidden meaning underlying the uttered statement (Keraf, 2007).

"Bu Tejo: ini tu keadaannya darurat mbok tolong to pak... nuraninya itu dipake pak, empatinya itu loh pak Ya Allah (it's an emergency, sir please sir... Use your consciousness and empathetic, sir. Ya Allah)

Police: sabar... sabar buk ngeh (Be patient... be patient ma'am)

$\mathrm{Bu}$ Tejo: apa tak telponke saudara saya yang polisi apa gimana? Hah? Bintangnya lima jejer berani apa? (should I Call my brother who's a police officer? 5 stars lined up, you dare!)

In the statement, " Bintangnya lima jejer berani apa?" (Should I Call my brother who's a police officer? 5 stars lined up, you dare!), it is an ironic satire expressed by $B u$ Tejo. The phrase 'bintangnya lima jejer' means a rank owned by the police officer. Still, in this context, $B u$ Tejo insinuated someone who took 
advantage of the connections of one of his family members or claimed to have a connection with someone who had a higher rank in the police to avoid being punished for violating the rules. Additionally, Bu Tejo's ironic style reminded the police officer that her brother held a higher and more critical position. It demonstrates that Bu Tejo's irony satire is exaggerated for her interlocutor. By combining an ironic tone with rhetorical tactics, specifically exaggeration, one can demonstrate criticism and convey feelings of disapproval to the interlocutor by accentuating the negative side (Maghfir, 2017).

\section{Sarcasm}

Sarcasm is derived from the Greek term 'sarkosmos,' which is simplified to the verb 'sakasein,' which means 'to shred flesh like a hound' or 'to speak harshly.' Sarcasm is believed to be harsher than irony and cynicism, as sarcasm is the use of words by someone that is highly unpleasant and contains bitterness (Keraf, 2007). According to Tarigan (2013), sarcasm may or may not be humorous, but the manner of sarcasm can be hurtful to people's feelings, and the words stated are unpleasant to hear. The following is an example of sarcasm from $B u$ Tejo in the film.

"Ibu Tri: Heh Yu Ning piye e jeneng e internet ki gawenane wong pinter je yo ora bakal keliru to yo ono-ono wae ho'oh to bu Tejo? (Hey Yu Ning! The internet is made by intelligent people who can't be wrong. isn't that right, Bu Tejo?)"

"Ibu Tejo: hehe lah Iyo hehe lek bodo ra mungkin iso gawe internet to yo (Yeah, it's true, if you are stupid, it's impossible to make the internet)."

In Bu Tejo's conversation, there was a sarcastic satire, namely the word 'Bodo,' which means "stupid" or not understanding immediately. Bu Tejo's sarcastic expression demonstrates that ignorant individuals are incapable of using and creating something valuable for others, such as the internet. Only intelligent individuals are capable of creating the internet. Bu Tejo's sarcasm seemed cruel and harsh, but she intended to convey that Mrs. Tri's statement was accurate if intellectual people were regarded as superior to stupid people. Bu Tejo's straightforward speaking style revealed that when the term 'bodo' was used. It was already widely used and understood in a language that was expected since there were worse terms for Javanese people to refer to those who do not comprehend a situation or understand a matter. On the other hand, the phrase 'bodo' is occasionally used as a joke to indicate closeness, but the person who uses it truly intends to speak sarcastically. It is consistent with Zawawi and Maghfiroh's (2020) view that sarcasm is an impolite language style in both its form and meaning. Its use is contextual and planned, such as ridiculing, criticizing, demonstrating closeness, and making jokes.

"Supir trek: lah saiki ngene ae bu lek seng
dadi lurah Dian ae piye? (how about if Dian
runs the village,ma'am??)

$\mathrm{Bu}$ Tejo: wee ojok...ojok banget Ya Allah amit-amit.... Ya Allah desone dewe iso ambyar koyo ngono corone (No!, for God's sake! our village can be destroyed if it's like that)."

The utterance " Ya Allah desone dewe iso ambyar koyo ngono corone " is sarcasm spoken by Bu Tejo. The phrase "ambyar" or "destroyed" means broken or no longer in a complete form. Still, in this context, the phrase was uttered by $B u$ Tejo to criticize that if Dian was made the wife of the headman of the village, the village where $B u$ Tejo lived would become backward, and there would be divisions among community members. The reproach expressed by Bu Tejo in the form of a sarcasm innuendo can hurt people who are targeted using satire because the language used is extremely rude. The choice of diction or the words used to infer results in the impression of sarcasm (Marjan, Saleh, \& Azis, 2021).

\section{CONCLUSION}

This article explores Bu Tejo's satirical language in the film 'Tilik.' The results indicate that Bu Tejo employed three distinct styles of satire language in this film: irony, sarcasm, and cynicism. Bu Tejo's most frequently used satire was cynicism, while sarcasm was her least frequently used pattern. Bu Tejo's utterances contained satirical expressions of irony, cynicism, and sarcasm to convey ideas and 
opinions about a social problem. Additionally, $\mathrm{Bu}$ Tejo used satire to communicate her displeasure and demonstrate that what she stated about something or someone was accurate.

A satirical language is a form of communication that is frequently used to criticize and counsel someone who has committed an error for those who receive satire to become aware of their error. However, if someone asserts that satire language is indifferent to the setting and circumstances, this will result in problems between them. Therefore, if someone genuinely wants to say anything that is regarded as inappropriate to another, it is preferable to use formal language and convey those words in such a way that there are no misconceptions.

\section{REFERENCES}

Agustina, J., \& Mardiana, M. (2019). Pengaruh Film Indie (Independent) terhadap Keterampilan Menulis Cerpen Siswa Kelas XI SMA Negeri 1 Talang Kelapa. Jurnal Pembahsi (Pembelajaran $\begin{array}{llll}\text { Bahasa Dan Sastra Indonesia), } & \text { 9(2), }\end{array}$ doi:http://dx.doi.org/10.31851/pembahsi.v9i2.4297

Annissa, Sihombing, R., Siregar, S. R., \& Hutagalung, T. (2020). Analisis Gaya Bahasa dalam Cerpen "Tio Na Tonggi" Karya Hasan Al Banna. Asas:Jurnal Sastra, 9(1), 33-44.

Ardianto, E., Komala, L., \& Karlinah, S. (2007). Komunikasi Massa: Suatu Pengantar. Bandung: Simbiosa Rekatama Media.

Arikunto, S. (2010). Prosedur Penelitian Suatu Pendekatan Praktik. Jakarta: RIneka Cipta.

Arisnawati, N. (2020). Gaya Bahasa Sindiran sebagai Bentuk Komunikasi Tidak Langsung dalam Bahasa Lailoyo. Medan Makna Jurnal Ilmu kebahasaan dan Kesastraan, 18(2), 136-148. doi:https://doi.org/10.26499/mm.v18i2.2314

Cahyo, A. N., Manullang, T. A., \& Isnan, M. (2020). Analisis Penggunaan Gaya Bahasa Sarkasme pada Lagu Bahaya Komunis Karangan Jason Ranti. ASAS : JURNAL SASTRA, 9(1), 6-22.

Effendy, O. U. (1986). Dimensi Dimensi Komunikasi. Bandung: Alumni.

Halimah, S. N., \& Hilaliyah, H. (2019). Gaya Bahasa Sindiran Najwa Shihab dalam Buku Catatan Najwa. DEIKSIS, 11(2), 157-165. doi:10.30998/deiksis.v11i02.3648

Heru, A. (2018). Gaya Bahasa Sindiran Ironi, Sinisme, dan Sarkasme dalam Berita Utama Harian Kompas. PEMBAHSI Jurnal Pembelajaran Bahasa dan Sastra Indonesia, 8(2), 43-54.

Ibrahim, S. (2015). Analisis Gaya Bahsa dalam Kumpulan Novel Mimpi Bayang Jingga Karya Sanie B. Kuncoro. Jurnal Sasindo Unpam, 3(3), 35-57.

Irawanto, B. (2017). Film, Ideologi, dan Militer: Hegemoni Militer dalam Sinema Indonesia Edisi II. Yogyakarta: Warning Books, Jalan Baru, \& INSISTPress.

Kartika, D., Putri, P. I., Wahyuningtiyas, R., \& Waljinah, S. (2019). Analisis Konteks Gaya Bahasa Berita Hoax Debat Capres di Media Sosial Facebook. Proceeding of The 11th University Research Colloquium 2020: Bidang Pengabdian Masyarakat (pp. 190-193). Yogyakarta: LPPM UMS.

Keraf, G. (2007). Diksi dan Gaya Bahasa. Jakarta: PT Gramedia Pustaka Utama.

Klarer, M. (2004). An Introduction to Literary Studies Second Edition. London and New York: Routledge. 
Maghfir, T. A. (2017). Penggunaan Gaya Bahasa Ironi dalam Dorama Hana Yori Dango Karya Yashuharii Ishii. Jurnal Asa, 4, 84-110.

Mara, R. S., \& Bahry, R. (2019). Analisis Gaya Bahasa Sindiran dalam Syair Didong Jalu Arita Mude dan Biak Cacak. Jurnal Bahasa dan Sastra, 13(1), 61-79.

Marjan, Saleh, M., \& Azis. (2021). Penggunaan Gaya Bahsa Sindiran dalam Webtoon Pak Guru Intong Karya Anggoro Ihank. Jurnal Pembelajaran Bahasa dan Sastra Indonesi, 2(3), 146-155. doi:https://doi.org/10.26858/indonesia.v2i3.23996

Masni, H., \& Yani, P. (2019). Bentuk-bentuk Gaya Bahasa Sindiran Pada Film Comic 8 Kasino King Part 2 Karya Anggy Umbara (Analisis Strutural). Aksara: Jurnal Ilmiah Pendidikan Bahasa dan Sastra Indonesia, 3(2), 196-207.

Mudjiono, Y. (2011). Kajian Semiotika dalam Film. Jurnal Ilmu Komunikasi, 1(1), 126-138. doi:https://doi.org/10.15642/jik.2011.1.1.125-138

Mudjiono, Y. (2011). Kajian Semiotika dalam Film. Jurnal Ilmu Komunikasi, 1(1), 126-138. doi:10.15642/jik.2011.1.1.125-138

Muhsyanur. (2015). Telaah Sarkasme Pada Judul Berita Dalam Surat Kabar Palopo Pos. Seminar Nasional Prasasti II "Kajian Pragmatik Dalam Berbagai Bidang” (pp. 269-274). Solo: Program Studi S3 Linguistik PPs UNS.

Nurlia, R., Patriantoro, \& Muzammil, A. R. (2019). Dieksi Bahasa Melayu Dialek Sambas dalam Film Kuali Hangus. Jurnal Pendidikan dan Pembelajaran Khatulistiwa, 8(9), 1-11.

Permana, R. S., Puspitasari, L., \& Indrian, S. S. (2019). Makna FIlm bagi Masyarakat Aceh. Jurnal Ilmu Politik dan Komunikasi, IX(1), 25-37.

Putri, A. I. (2019). Analisis Gaya Bahasa Artis pada MEdia Sosial. Seminar Bahasa dan Sastra Indonesia, 2(1), 112-120.

Rashid, S. N., \& Yaakob, N. A. (2017). Jenis Bahasa Sindiran dalam Ujaran Vlog. International Journal of Language Education and Applied Linguistics (IJLEAL), 7, 17-29.

Riyadi, S. (2014). Penggunaan Film Adaptasi sebagai Media Pengajaran Sastra. Bahasa dan Sastra, 14(2), 214-251.

Sari, S., Hartati, Y. S., \& Satini, R. (2021). GayaBAHASA PERBANDINGAN DALAM NOVEL ENTROK KARYA OKKY MADASARI. Jurnal Inovasi Penelitian, 1(11), 2499-2504. doi:https://doi.org/10.47492/jip.v1i11.499

Sari, Y. P., Missriani, \& Wandiyo. (2021). Analisis Gaya Bahasa pada Film DIlan 1990 Karya Pidi Baiq. PEMBAHSI JURNAL PEMBELAJARAN BAHASA INDONESIA, 11(1), 10-16. doi:10.31851/pembahsi.v11i1.4317

Solekhati, N. F. (2016). Pemakaian Gaya Bahasa Sindiran pada Acara "Sentilan Sentilun" di Televisi. Jurnal Bahasa Dan Sastra Indonesia,, 5(5), 1-13.

Subandi, S. M., \& Galih Wibisono, B. M. (2017). Pengguanaan Gaya Bahasa Sindiran dalam Film Xiao Haizi Bu Ben 2 《小孩子不笨 2》. Mandarin Unesa, 0-7.

Sya'Dian, T. (2016). Bunkasai, Kajian Semiotika Budaya Kontemporer dari Pengaruh Film Jepang. Jurnal Proporsi, 2(1), 35-47. doi:http://dx.doi.org/10.22303/proporsi.2.1.2016.35-47 
Tarigan, H. G. (2013). Pengajaran Gaya Bahasa. Bandung: Angkasa Bandung.

Waridah, E. (2010). EYD; Ejaan yang Disempurnakan \& Seputar Kebahasa-Indonesiaan. Jakarta: Ruang Kata.

Wijana, I. D., \& Rohmadi, M. (2006). Sosiolinguistik : Kajian teori dan analisis. Yogyakarta: Pustaka Pelajar.

Winokur, M., \& Holsinger, B. (2001). The Complete Idiot's Guide to Movies,Flicks, and Films. Indianapolis: Alpha Books.

Zawawi, M., \& Maghfiroh, D. L. (2020). Sarcasm and the Translation Quality in The Subtle Art Of Not Giving A Fuck Book. LiNGUA, 15(2), 254-260. 